\title{
Metastasis of a Dorsal Melanoma to a Pituitary Adenoma Mimicking Pituitary Apoplexy
}

\section{Metástase de um melanoma dorsal em um adenoma hipofisário imitando apoplexia pituitária}

\author{
Rui Ramos ${ }^{1}$ Maria João Machado ${ }^{1}$ Cristiano Antunes ${ }^{1}$ Vera Fernandes ${ }^{2}$ Olinda Marques ${ }^{2}$ \\ Rui Almeida ${ }^{1}$ \\ ${ }^{1}$ Department of Neurosurgery, Hospital de Braga, Braga, Portugal \\ ${ }^{2}$ Department of Endocrinology, Hospital de Braga, Braga, Portugal \\ Address for correspondence Rui Ramos, Department of \\ Neurosurgery, Hospital de Braga, R. das Sete Fontes, 4710, São Victor, \\ 4710-243 Braga, Portugal (e-mail: ruimramos@hotmail.com).
}

Arq Bras Neurocir 2017;36:238-242.

\begin{abstract}
Keywords

- tumour-to-tumor metastasis

- pituitary adenoma

- melanoma

- apoplexy

\section{Resumo}

\section{Palavras-chave}

- metástase tumortumor

- adenoma hipofisário

- melanoma

- apoplexia

Metastases to pituitary adenomas are very rare. From the 20 cases found in the literature, none originated from a cutaneous melanoma.

We present the case of a 67-year-old man with a history of transcranial approach to treat a pituitary macroadenoma followed by adjuvant radiotherapy. Fifteen years later, he presented a dorsal nodular melanoma, and three years after that, he developed symptoms of pituitary apoplexy. He was submitted to transsphenoidal surgery, and the histology result revealed metastasis of the melanoma into a pituitary adenoma.

The similarity in the clinical presentation of the two entities-pituitary apoplexy and metastasis of the melanoma into a pituitary adenoma-and the rarity of this type of metastization alert to challenges in the differential diagnosis that may confound the neurosurgeon's decision.

As metástases em adenomas pituitários são muito raras. Dos 20 casos descritos na literatura, nenhum foi originado por um melanoma cutâneo.

Apresentamos um caso de um homem de 67 anos de idade, com história de abordagem transcraniana para tratar um macroadenoma pituitário, seguido de radioterapia adjuvante. Quinze anos depois, o paciente apresentou um melanoma nodular dorsal e 3 anos mais tarde desenvolveu sintomas de apoplexia pituitária. Ele foi então submetido a uma cirurgia transfenoidal, e o resultado histológico revelou tratar-se de uma metástase do melanoma em um adenoma hipofisário.

A semelhança na apresentação clínica entre as duas entidades-apoplexia pituitária e metástase do melanoma em um adenoma hipofisário - e a raridade deste tipo de metastização alertam para desafios no diagnóstico diferencial que podem confundir a decisão do neurocirurgião.
\end{abstract}

received

August 7, 2017

accepted

October 17, 2017

published online

November 30, 2017
DOI https://doi.org/

$10.1055 / \mathrm{s}-0037-1608907$.

ISSN 0103-5355.
Copyright @ 2017 by Thieme Revinter

Publicações Ltda, Rio de Janeiro, Brazil
License terms

(c) $(1) \$$ 


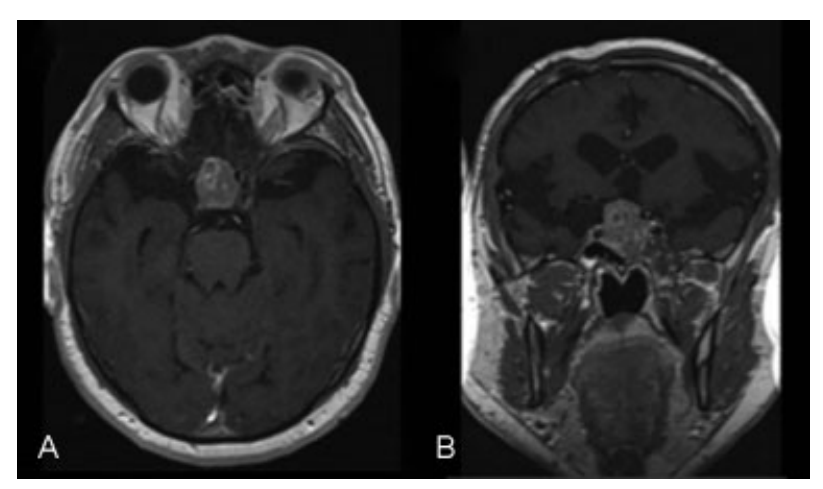

Fig. 1 Brain MRI in December of 2012, 1 year before the apoplexy. Gadolinium-enhanced T1-weighted axial (A) and coronal (B) images showing a sellar/suprasellar/sphenoidal lesion measuring $21 \times 30 \mathrm{~mm}$, heterogeneous signal, compressing of the optic chiasm and invasion of the cavernous sinus.

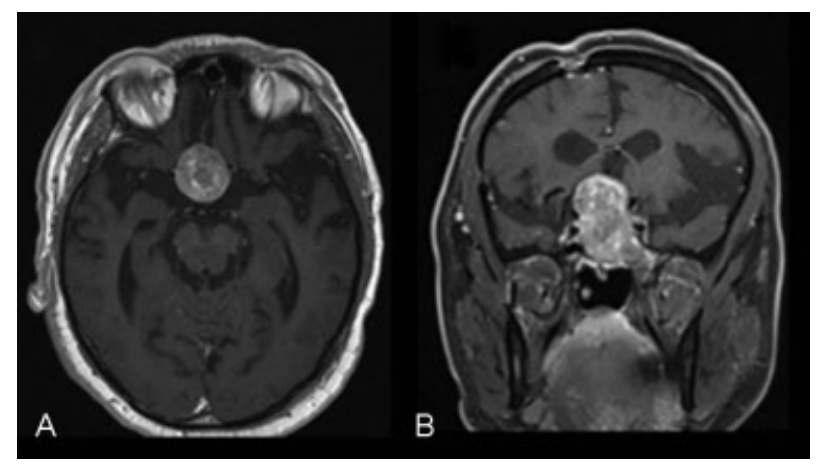

Fig. 2 Brain MRI in December of 2013, after the apoplexy and before the transsphenoidal surgery. Gadolinium-enhanced T1-weighted axial (A) and coronal (B) images showing a sellar/suprasellar/sphenoidal lesion measuring $26 \times 42 \mathrm{~mm}$ and heterogeneous signal.

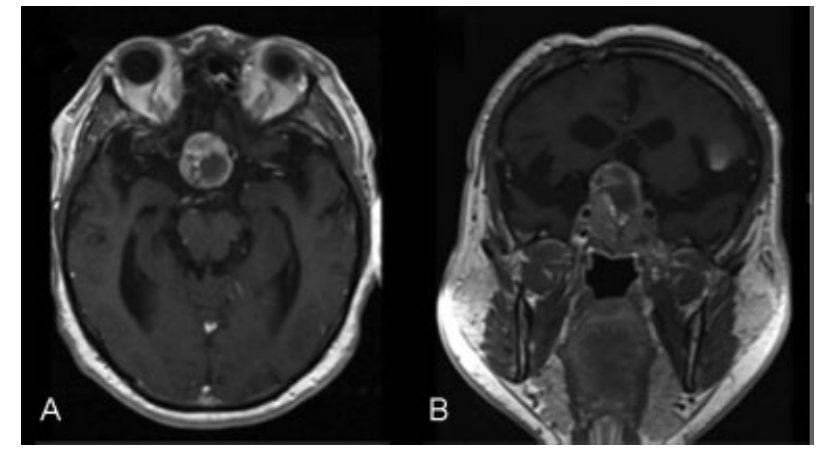

Fig. 4 Brain MRI two months after the transsphenoidal surgery. Gadolinium-enhanced T1-weighted axial (A) and coronal (B) images showing regrowth of the sellar/suprasellar lesion and a new left frontal-opercular lesion.

\section{Introduction}

Tumor-to-tumor metastasis is a well-known phenomenon since its first observation, in 1930 , by Fried et al in a case of bronchogenic carcinoma metastasis to an intracranial meningioma. ${ }^{1}$

The definition of a tumor-to-tumor metastasis needs to meet the following criteria: 1.) presence of more than one primary tumor; 2 .) the receiver tumor has to be a true neoplasm; 3.) the tumor donor should be a source of metastasis; 4.) tumors that metastasize through the lymphatic system where lymphoreticular tumors already exist are not included. ${ }^{1}$

The most common intracranial receptors for visceral metastasis are meningiomas, but other tumors like low grade gliomas, ependymomas, schwannomas, hemangioblastomas and pituitary adenomas have also been reported. ${ }^{2}$
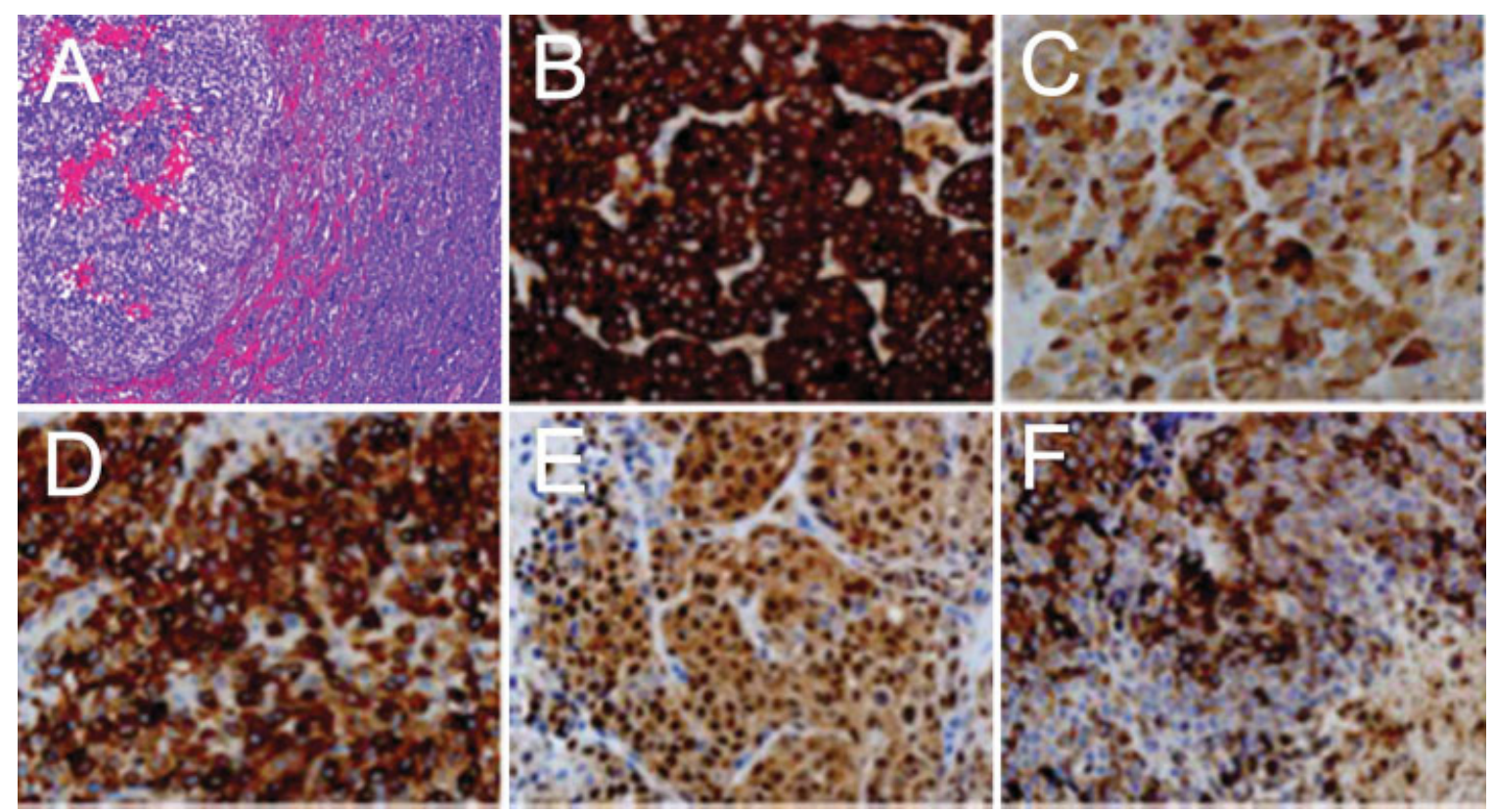

Fig. 3 Histologic tissue sections. Hematoxylin and eosin (A), 100 $\times$ original magnification showing melanoma cells on the left and adenoma cells on the right. Synaptophysin (B) and follicle-stimulating hormone (FSH) (C) positive staining it the adenoma cells. Melan-A (D), microphthalmia transcription factor (Mitf) (E) and human melanoma black (HMB)-45 (F) positive staining in the melanoma cells. 


\begin{tabular}{|c|c|c|c|c|c|c|c|c|c|c|c|c|c|c|c|c|c|c|c|c|}
\hline 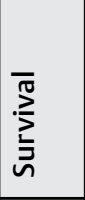 & $\sim$ & 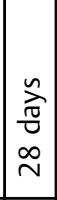 & 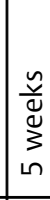 & $\sim$ & $\sim$. & 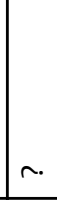 & $\begin{array}{l}\widetilde{n} \\
\underset{\tilde{D}}{0} \\
\simeq\end{array}$ & $\begin{array}{l}\frac{\tilde{u}}{\tilde{\Xi}} \\
\tilde{\Xi} \\
m\end{array}$ & $\sim$ & 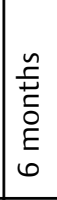 & $\curvearrowright$ & 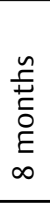 & 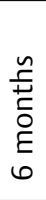 & \begin{tabular}{l}
$\tilde{n}$ \\
+ \\
\multicolumn{1}{c}{} \\
हे \\
6
\end{tabular} & $\curvearrowright$. & $\mid \begin{array}{c}E \\
\infty \\
\ulcorner \\
\wedge\end{array}$ & $\begin{array}{l}E \\
6 \\
\wedge\end{array}$ & 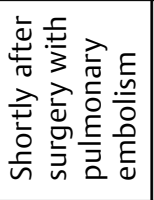 & $\begin{array}{l}\tilde{\widetilde{\sigma}} \\
\underset{\sigma}{\tilde{m}} \\
m\end{array}$ & $\sim$. \\
\hline 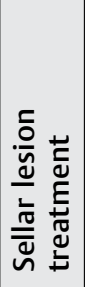 & 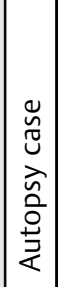 & 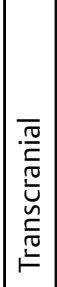 & 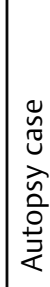 & 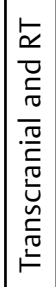 & 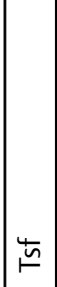 & n. & 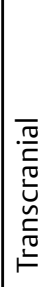 & $\stackrel{\llcorner}{\alpha}$ & 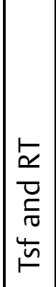 & 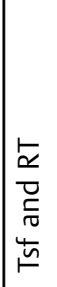 & 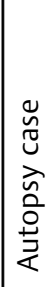 & 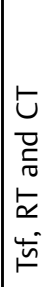 & $\stackrel{4}{\check{n}}$ & $\overline{\check{n}}$ & $\stackrel{4}{\tilde{n}}$ & $\sqrt[4]{n}$ & $\mid \stackrel{4}{\sim}$ & 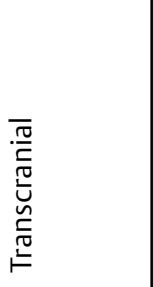 & $\overleftarrow{\check{n}}$ & $\stackrel{\tilde{n}}{n}$ \\
\hline
\end{tabular}

胥

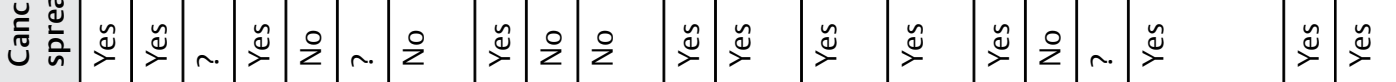

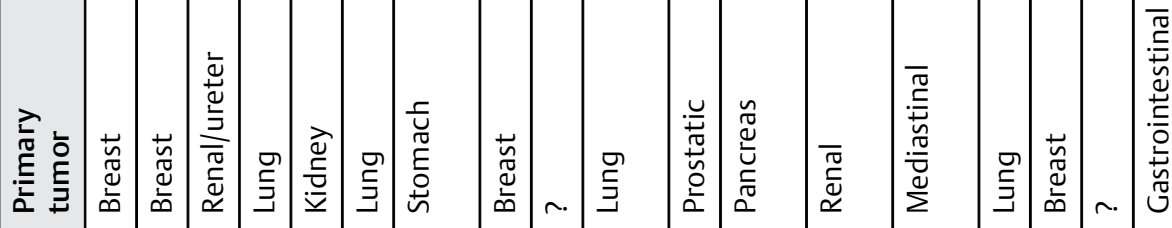

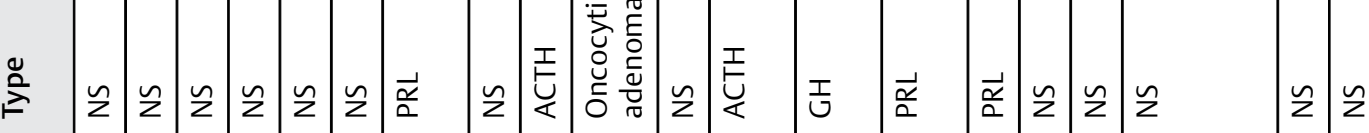

$\frac{\vec{x}}{\frac{u}{0}}$

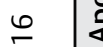

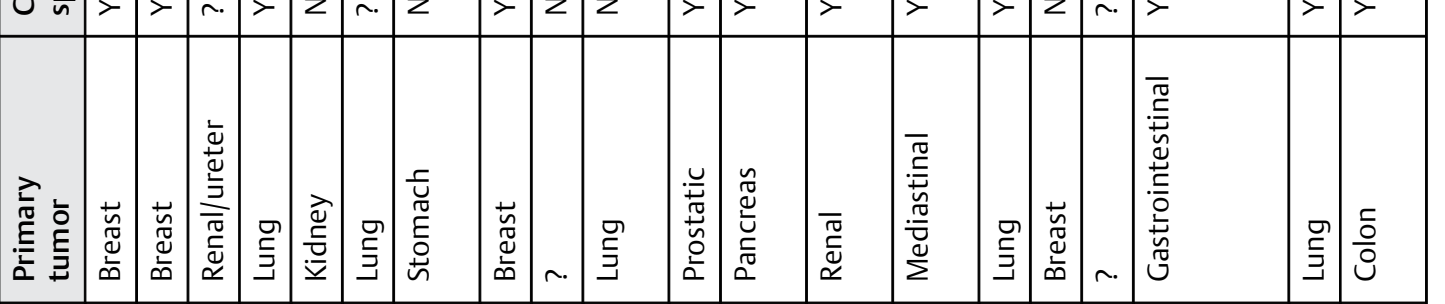

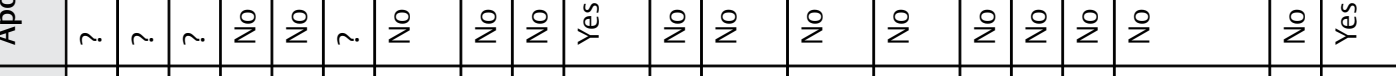

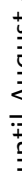

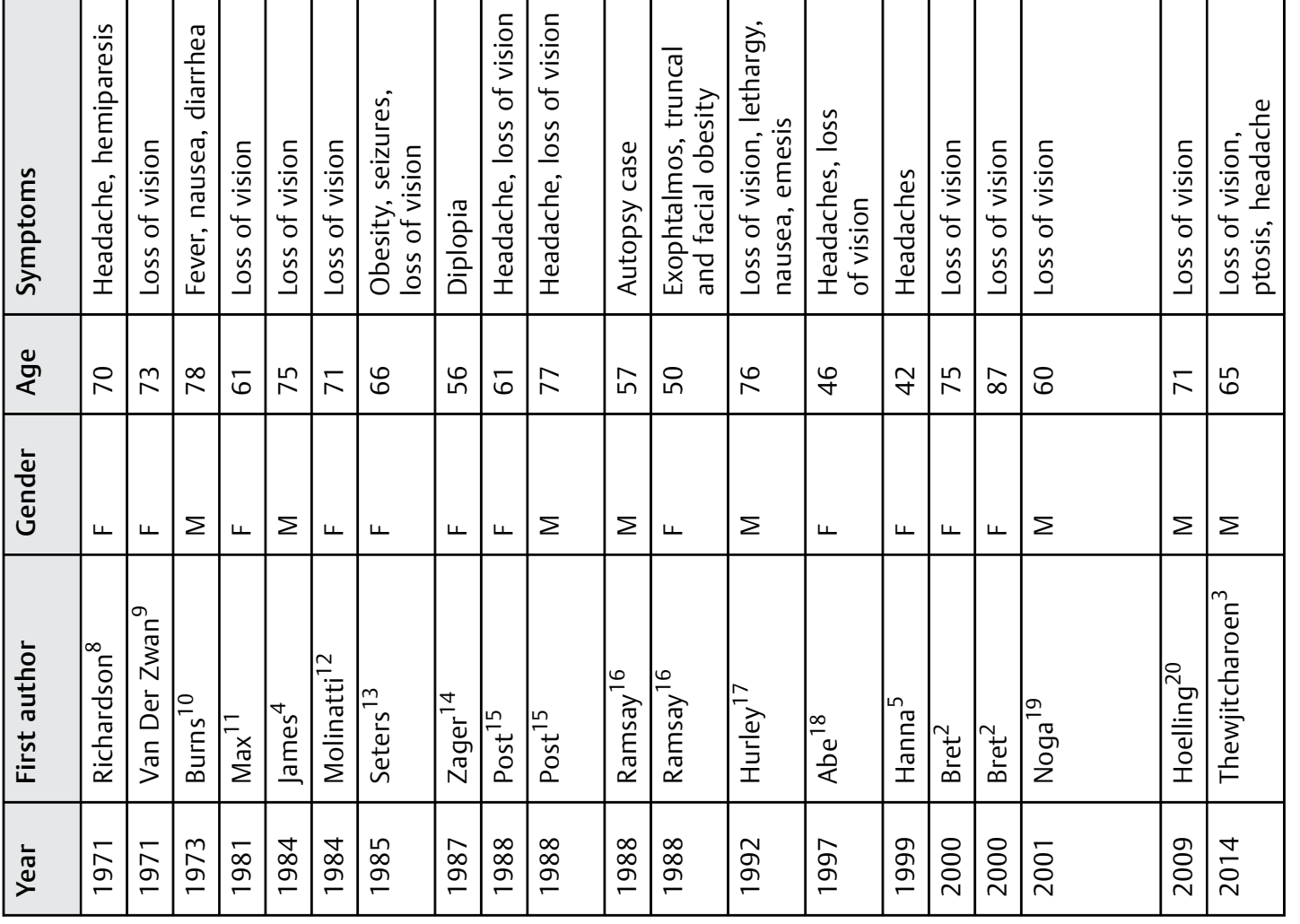


The rare phenomenon of metastasis to a pituitary adenoma may be explained by different factors: 1.) the abnormal vasculature and the hormonal effect of the adenoma with the ability to increase cellular proliferation; ${ }^{3}$ 2.) the increased microvasculature produced by surgery or radiation to an adenoma; ${ }^{2}$ 3.) the slow growth of the adenomas, which creates an environment without competition to the growth of the metastasis. ${ }^{3}$ Finally, due to its rarity, the tumor-totumor metastasis can be a simple coincidence. ${ }^{3}$

The clinical and imaging features of pituitary metastasis are often similar to those of a pituitary adenoma. ${ }^{3}$ In many cases, the pituitary metastases are asymptomatic. ${ }^{4}$ In symptomatic patients, the most frequent presentations are diabetes insipidus, visual disturbances, cranial nerves palsy, and anterior hypopituitarism. ${ }^{5}$ Another possible clinical presentation is pituitary apoplexy. The apoplexy occurs as result of hemorrhaging or infarction of a rapidly growing preexisting adenoma. ${ }^{6}$ It manifests as an acute-onset headache, vomiting, decreased visual acuity, ophthalmoplegia and decreased level of consciousness. ${ }^{7}$ It usually occurs in pituitary macroadenomas, but it has also been described in normal pituitary gland, craniopharyngiomas, lymphocytic hypophysitis and

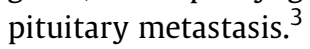

On the magnetic resonance imaging (MRI), the pituitary metastases are similar to pituitary adenomas and present as intra and suprasellar homogeneous masses without ring enhancement and areas of necrosis. ${ }^{2}$ They may present isosignal in T1- and T2-weighted images and loss of the neurohypophysis bright signal. ${ }^{3}$ On the other hand, melanin appears with hypersignal on T1 and hyposignal on T2-weighted images. ${ }^{7}$ Lastly, hemorrhagic metastases can result in the same type of signal on T1- and T2-weighted images, but they have a more heterogeneous pattern. ${ }^{7}$

The intraoperative findings are not different between the two lesions, but some authors have reported an atypical presentation of the metastasis, exhibiting hard texture, hemorrhage or both components. ${ }^{2}$

The poor prognosis in case of metastasis to a pituitary adenoma depends on the fact that many patients already have extensive metastatic spread when diagnosed. ${ }^{3}$ The average survival of a pituitary metastasis is about 6 months. ${ }^{3}$

The treatment options are limited, but the patients may be given palliative radiotherapy, hormone replacement therapy and chemotherapy for the primary tumor. ${ }^{3}$

\section{Case Report}

We describe the case of a 67-year-old male patient followed up in our pituitary group outpatient clinic since 1995, after a pituitary macroadenoma had been diagnosed as the cause of visual amputation. He underwent a craniotomy followed by adjuvant radiotherapy and started on levothyroxine, hydrocortisone, and testosterone because of hypopituitarism. Since then his clinical state was stable.

In 2010, a dorsal nodular melanoma, Clark level IV, was excised.

The baseline images of the adenoma remained stable over the years, the last one dated from December 2012 (-Fig. 1).
In December of 2013, he entered the emergency room after a sudden onset of headache, vomiting and decreased visual acuity in the left eye. Brain computed tomography and MRI (-Fig. 2) suggested pituitary apoplexy, and he underwent partial removal of the lesion by transsphenoidal approach. During the procedure, we found a hemorrhagic lesion with heterogeneous consistency. Some areas were very soft and similar to adenoma and others were stiff with some foci of chronic hemorrhaging.

The histological result revealed a melanoma metastasis within the pituitary adenoma (-Fig. 3). After the surgery, the patient's clinical state improved, but 2 months later he presented with nausea and vomiting. The MRI revealed regrowth of the sellar/suprasellar lesion reaching similar dimensions to those before surgery, but a new left frontal opercular lesion was visible (-Fig. 4). The patient died 3 months later.

\section{Discussion}

This patient had been previously submitted to surgery and radiotherapy due to a pituitary macroadenoma. He remained stable for 18 years, but 7 years ago he was diagnosed with a dorsal melanoma. Suddenly, he presented with unexpected symptoms suggesting pituitary apoplexy. The presence of a marked visual deficit conducted to an early surgical intervention.

Although apoplexy is more frequent in untreated macroadenomas, and tumor-to-tumor metastases are extremely rare, the severity of visual complications in this case misled the surgeons to an emergent surgical approach, since they attributed the symptoms to classic apoplexy.

A literature search conducted in PubMed until August of 2016 yielded 20 cases of metastasis to pituitary adenomas. The results have been summarized in - Table 1 . We did not find any cases of melanoma metastization to a pituitary adenoma, but only cases of melanoma metastasis to a normal pituitary gland. As in our case, the presenting symptoms were compatible with pituitary apoplexy and surgery or autopsy confirmed this very rare diagnosis.

\section{Conclusions}

Two different clinical entities, such as pituitary apoplexy and a melanoma metastasis to a pituitary adenoma, present with very similar clinical, imagiological and surgical findings. The rarity of tumor-to-tumor metastasis and the need for an emergent decision facing acute visual loss compatible with pituitary apoplexy of a residual tumor led the surgeons to elect surgical intervention as the treatment of choice. The histology revealing a melanoma metastasis within the residual adenoma highlighted the need to value differential diagnosis that may confound the surgeon's decision.

This case alerts neurosurgeons to the possibility of a metastasis to a pituitary adenoma when there is the coexistence of another tumor highly prone to metastization.

Conflict of Interest

Authors declare no conflict of interest. 


\section{References}

1 Erdogan H, Aydin MV, Tasdemiroglu E. Tumor-to-tumor metastasis of the central nervous system. Turk Neurosurg 2014;24(02):151-162

2 Bret P, Jouvet A, Madarassy G, Guyotat J, Trouillas J. Visceral cancer metastasis to pituitary adenoma: report of two cases. Surg Neurol 2001;55(05):284-290

3 Thewjitcharoen Y, Shuangshoti S, Lerdlum S, Siwanuwatn R, Sunthornyothin S. Colorectal cancer manifesting with metastasis to prolactinoma: report of a case involving symptoms mimicking pituitary apoplexy. Intern Med 2014;53(17):1965-1969

4 James RL Jr, Arsenis G, Stoler M, Nelson C, Baran D. Hypophyseal metastatic renal cell carcinoma and pituitary adenoma. Case report and review of the literature. Am J Med 1984;76(02):337-340

5 Hanna FW, Williams OM, Davies JS, Dawson T, Neal J, Scanlon MF. Pituitary apoplexy following metastasis of bronchogenic adenocarcinoma to a prolactinoma. Clin Endocrinol (Oxf) 1999;51(03):377-381

6 Abdulbaki A, Kanaan I. The impact of surgical timing on visual outcome in pituitary apoplexy: Literature review and case illustration. Surg Neurol Int 2017;8:16

7 Masui K, Yonezawa T, Shinji Y, Nakano R, Miyamae S. Pituitary apoplexy caused by hemorrhage from pituitary metastatic melanoma: case report. Neurol Med Chir (Tokyo) 2013;53(10):695-698

8 Richardson JF, Katayama I. Neoplasm to neoplasm metastasis. An acidophil adenoma harbouring metastatic carcinoma: a case report. Arch Pathol 1971;91(02):135-139

9 van der Zwan A, Luyendijk W, Bots GT. Metastasis of mammary carcinoma in a chromophobe adenoma of the hypophysis. Psychiatr Neurol Neurochir 1971;74(05):369-377

10 Burns WA, Kadar AT. Unusual metastases from a transitional-cell carcinoma of the renal pelvis and ureter. Med Ann Dist Columbia 1973;42(02):65-66
11 Max MB, Deck MD, Rottenberg DA. Pituitary metastasis: incidence in cancer patients and clinical differentiation from pituitary adenoma. Neurology 1981;31(08):998-1002

12 Molinatti PA, Scheithauer BW, Randall RV, Laws ER Jr. Metastasis to pituitary adenoma. Arch Pathol Lab Med 1985;109(03):287-289

13 van Seters AP, Bots GT, van Dulken H, Luyendijk W, Vielvoye GJ. Metastasis of an occult gastric carcinoma suggesting growth of a prolactinoma during bromocriptine therapy: a case report with a review of the literature. Neurosurgery 1985;16(06):813-817

14 Zager EL, Hedley-Whyte ET. Metastasis within a pituitary adenoma presenting with bilateral abducens palsies: case report and review of the literature. Neurosurgery 1987;21(03):383-386

15 Post KD, McCormick PC, Hays AP, Kandji AG. Metastatic carcinoma to pituitary adenoma. Report of two cases. Surg Neurol 1988;30 (04):286-292

16 Ramsay JA, Kovacs K, Scheithauer BW, Ezrin C, Weiss MH. Metastatic carcinoma to pituitary adenomas: a report of two cases. Exp Clin Endocrinol 1988;92(01):69-76

17 Hurley TR, D’Angelo CM, Clasen RA, DiGianfilippo A, Ryan WG. Adenocarcinoma metastatic to a growth-hormone-secreting pituitary adenoma: case report. Surg Neurol 1992;37(05):361-365

18 Abe T, Matsumoto K, Iida M, Hayashi M, Sanno N, Osamura RY Malignant carcinoid tumor of the anterior mediastinum metastasis to a prolactin-secreting pituitary adenoma: a case report. Surg Neurol 1997;48(04):389-394

19 Noga C, Prayson RA, Kowalski R, Sweeney PJ, Mayberg M. Metastatic adenocarcinoma to a pituitary adenoma. Ann Diagn Pathol 2001;5(06):354-360

20 Hoellig A, Niehusmann P, Flacke S, Kristof RA. Metastasis to pituitary adenoma: case report and review of the literature. Cent Eur Neurosurg 2009;70(03):149-153 